\title{
AMINO ACID ANALYSIS AND BIOLOGICAL EVALUATION OF DETOXIFIED THEVETIA SEED MEAL
}

\section{${\text { Oluwaniyi } \text { OO }^{1 *} \text {, Ibiyemi SA }}^{1}$, Olatunji GA ${ }^{1}$ and DF Apata ${ }^{2}$}

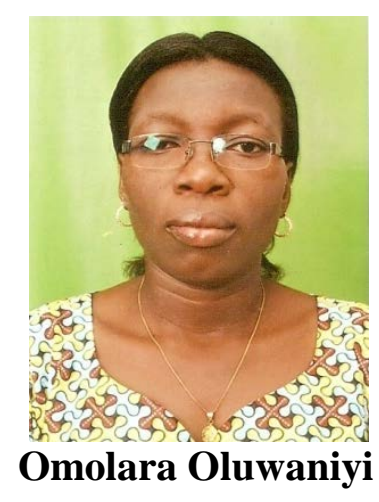

*Corresponding author email: laraoluwaniyi@yahoo.com

${ }^{1}$ Department of Chemistry, University of Ilorin, P.M.B. 1515, Ilorin Nigeria.

${ }^{2}$ Department of Animal Production, University of Ilorin, P.M.B. 1515, Ilorin Nigeria. 


\section{ABSTRACT}

Thevetia peruviana seed meal was detoxified using two methods - acid hydrolysis followed by ethanolic extraction of the released aglycones and direct ethanolic extraction of the cardiac glycosides. Acid detoxification followed by alcoholic extraction of the aglycones gave a meal with 95\% reduction in the glycoside content (from 42.7 to $2.15 \mathrm{~g} \mathrm{~kg}^{-1}$ ), while direct alcohol detoxification led to a $98 \%$ reduction in the glycoside content of the seed meal (from 42.7 to $0.83 \mathrm{~g} \mathrm{~kg}^{-1}$ ). The two treated Thevetia seed meals (TSM) were used to formulate poultry diets by introducing 0,5 , 10 and $15 \%$ of treated TSM into the feed composition which is equivalent to $0,16.7$, 33.3 and 50\% replacement of soybean meal. The results showed that up to $15 \%$ inclusion of alcohol detoxified TSM $(\approx 50 \%$ replacement of soybean meal) produced no mortality and gave satisfactory growth performance of the cockerels used for the experiment. The performance of birds on alcohol detoxified diets was comparable with that of birds on the control diet. However, diets formulated with acid detoxified TSM gave fairly satisfactory performance only with 5\% inclusion of the detoxified meal in the diet (i.e., $16.7 \%$ replacement of soybean in the meal). Higher inclusion levels (5 and 10\% inclusions) resulted in reduced feed intake and retention, reduced activity and high mortality ( 25 - 33\% mortality). The birds were uncoordinated, walked limply and generally exhibited poor growth performance. Amino acid analysis of the detoxified TSM also showed that the alcohol-detoxified meal had a better amino acid profile and higher essential amino acid contents than either the raw meal or the acid-detoxified meal. The acid-detoxified meal had the lowest content of all amino acids analyzed except the acid amino acids which were increased. Generally, alcohol detoxification appeared to be the best and most effective of the two detoxification methods examined.

Key words: Detoxification, cardiac-glycosides, Thevetia meal 


\section{INTRODUCTION}

Large segments of the population in developing countries suffer from protein malnutrition for want of adequate quantity and quality of protein in their diets. Projection based on current trends in human population growth and protein supply indicates that the gap will become increasingly wide in years to come [1]. There is an increase in animal protein demand needed to satisfy the growth in the human population and the increasing affluence of the emerging economies [2]. There is, therefore, a consequent rise in the demand for animal feed, not only of cereals but of other feeds and particularly proteins [2].

With the increase in the world protein demand and supply, oilseeds have continued to be relevant as major sources of protein in animal feed production [3]. Oilseeds are known to be important sources of fat and oil, and they also serve as major sources of useful protein, which is always contained in the cake remaining after the seed has been defatted. Most of these oilseeds are grown extensively in tropical and subtropical areas and many have been used as major sources of protein for both man and animal. The proteins in oilseeds can be fed either as part of the oil, intact seed, or as a meal from which the oil has been removed [4].

Most of the proteinaceous oilseeds on which work has been well documented namely cotton seed, cowpea, soybean, groundnut, and rapeseed are protein sources not just for animals but also for man [3, 5, 6, 7]. This has, therefore, led to a competition between man and animal for food, which consequently resulted in the scarcity and a high price of these oilseeds [8]. Hence, there is need to develop novel protein sources that will serve as food just for animal consumption, thereby eliminating the competition between man and animals. Nutritionists around the world are attempting to approach this problem by developing novel foods from non - conventional protein sources such as algae protein, single cell protein, insect protein [9]. Another approach to the problem is the detoxification of the many abundant oilseeds indigenous to the tropics, which are not yet fully utilized because of toxins and anti-nutrients in them. One such oilseed is Thevetia peruviana.

The determined proximate and amino acid composition of Thevetia seed meal suggests a plant protein source that could be potentially used for livestock feed. The seeds of this plant have been reported to be rich in protein. Steyn [10] and Nair et al. [11] reported about 35\% protein in Thevetia peruviana seeds. Ibiyemi et al. in a different study reported $37 \%$ crude protein in the seeds while Atteh et al. reported $47.5 \%$ protein in the seed $[12,13]$.

Despite the potentials of this plant for bridging the enlarging gap of protein deficiency and meeting the world's demand for high quality protein crops for livestock feed, there is no human dietary or commercial demand for the seeds due to the presence of the anti-nutritional, toxic cardiac glycosides and aglycones found in them [14, 15, 16, 17, 18, 19, 20, 21]. Several glycosides have been extracted from various parts of Thevetia peruviana plant, with the major one being thevetin [22, 23]. This toxin is responsible for the bitterness and very low palatability of the seed. If however it can

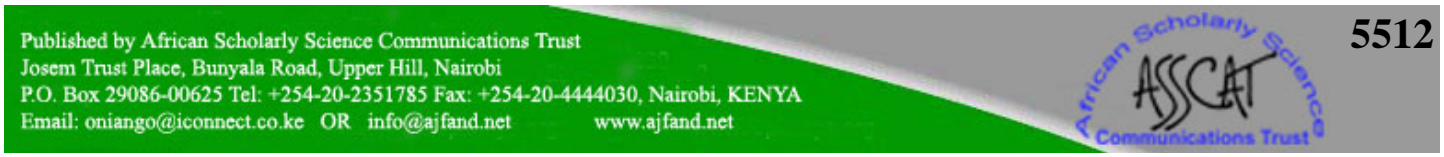


be removed from Thevetia, the detoxified seed will serve as an excellent and cheap source of protein for animal feed and ultimately lead to a reduction in the cost of poultry feed because it is not being consumed by man. Thevetia peruviana has the advantage of being able to grow in harsh conditions [12], can survive well in drought, does not require the use of fertilizers and it fruits profusely.

Previous attempts at the detoxification of Thevetia seed meal did not report a satisfactory result in the performance of animals fed with the detoxified meal [13, 24, 25]. This work therefore aimed at detoxifying Thevetia seed meal and evaluating the amino acid composition and nutritional quality of the detoxified meal.

\section{MATERIALS AND METHODS}

\section{Materials}

Matured fruits of Thevetia plant were collected from various locations in Ilorin, Kwara State, Nigeria, by direct plucking of black matured fruits from plants and also by picking those that had fallen off the plants. The fruits were cracked to remove the hard pericarp and mesocarp and the soft seeds were crushed into a paste. The paste was defatted first by mechanical pressing, followed by solvent extraction using predistilled n-hexane. The defatted cake was then air-dried and used for further experiments.

\section{Detoxification}

Two different methods were employed in the detoxification experiments. The first was the solvent extraction of the defatted seed meal using $80 \%(\mathrm{v} / \mathrm{v})$ aqueous alcohol mixture, while the second involved the hydrolysis of the cake with $0.1 \mathrm{M} \mathrm{HCl}$ prior to extraction with $80 \%$ aqueous ethanol. The detoxification experiments were carried out as reported previously [26]. The detoxified samples were air-dried (at ambient temperature) to remove residual solvent in them.

\section{Glycoside content determination}

The quantity of cardiac glycosides in the raw and treated samples was evaluated using Baljet's reagent (95 ml aqueous picric acid $+5 \mathrm{ml} 10 \%$ aqueous $\mathrm{NaOH}$ ) as described by El-Olemy et al. [27]. Each sample (1 g) was soaked in $10 \mathrm{ml}$ of $70 \%$ alcohol for $2 \mathrm{~h}$ and then filtered. The extracts obtained were purified using lead acetate and $\mathrm{Na}_{2} \mathrm{HPO}_{4}$ solutions before the addition of freshly prepared Baljet's reagent. The intensity (absorbance) of the colour produced was then measured at $495 \mathrm{~nm}$. The difference between the intensity of the colours of the experimental and blank (distilled water and Baljet's reagent) samples gave the absorbance and was proportional to the concentration of the glycoside. The analysis was done in triplicate.

\section{Amino acid analysis}

The amino acid profile of the raw and detoxified samples of TSM was determined by ion exchange chromatography using Technicon Sequential Multisample amino acid analyzer (Technicon Instruments Corporation, New York) after sample preparation according to the methods of the Association of Official Analytical Chemists (AOAC) [28]. The samples were dried to constant weight and about $2.0 \mathrm{~g}$ of each was defatted 
with chloroform / methanol (2:1 v/v mixture) using a Soxhlet extractor for about $5-6$ hours. The defatted samples were then hydrolyzed using $6 \mathrm{~N} \mathrm{HCl}$, filtered and the filtrate was evaporated to dryness in a rotary evaporator and then separated in the amino acid analyzer.

\section{Biological Evaluation of detoxified TSM}

Two groups of birds, each containing ninety six (96) day - old cockerels (Bovans nera strain) were used in the experiments. The birds were reared in an electrically heated battery brooder for 14 days on a proprietary diet. From day 15, the cockerels were fed the experimental diets shown in Table 1 . The diets contained the same nitrogen concentration. The dietary treatments were replicated four times, with six birds per replicate cage. Feed and water were given ad libitum for the duration of the experiments. The experiment lasted 14 days for the birds on the acid-detoxified diets and 21 days for birds on the alcohol-detoxified diets.

Performance indices of average weekly feed intake, weekly weight gain, feed efficiency ratio and mortality were determined from the start of the experiment and nutrient retention trial was undertaken at the second and third week of experiment for the birds on the acid-detoxified diets and those on the alcohol-detoxified diets, respectively.

To estimate the nutrient retention, protein nitrogen in feed and feacal samples was determined by the Kjeldahl procedure, fat by petroleum ether extraction using Soxhlet apparatus, ash by incineration of the samples in a muffle furnace maintained at $550^{\circ} \mathrm{C}$ for $5 \mathrm{~h}$; and crude fibre by digesting each sample with $1.25 \% \mathrm{H}_{2} \mathrm{SO}_{4}$ and $1.25 \%$ $\mathrm{NaOH}$ and incinerating the residue in a muffle furnace maintained at $550^{\circ} \mathrm{C}$ for $5 \mathrm{~h}$. All analyses were done according to the standard methods of the Association of Official Analytical Chemists [28].

\section{Statistical analysis}

Data were analyzed by the one way analysis of variance (ANOVA). Means were compared by the Duncan's Multiple Range Test; $(\mathrm{p}=0.05)$

\section{RESULTS}

\section{Cardiac glycoside content}

Figure 1 shows the content of cardiac glycoside, calculated as \% digitoxin, in the various Thevetia seed meal samples and the results showed a marked reduction in glycoside content irrespective of detoxification method employed. Acid detoxification resulted in reduction in the cardiac glycoside content from $4.27 \pm 0.24$ to $0.22 \pm 0.11$ $\%$ ( $\approx 95 \%$ reduction) while alcohol treatment gave a $98 \%$ reduction (from $4.27 \pm$ 0.24 to $0.08 \pm 0.04 \%)$. 

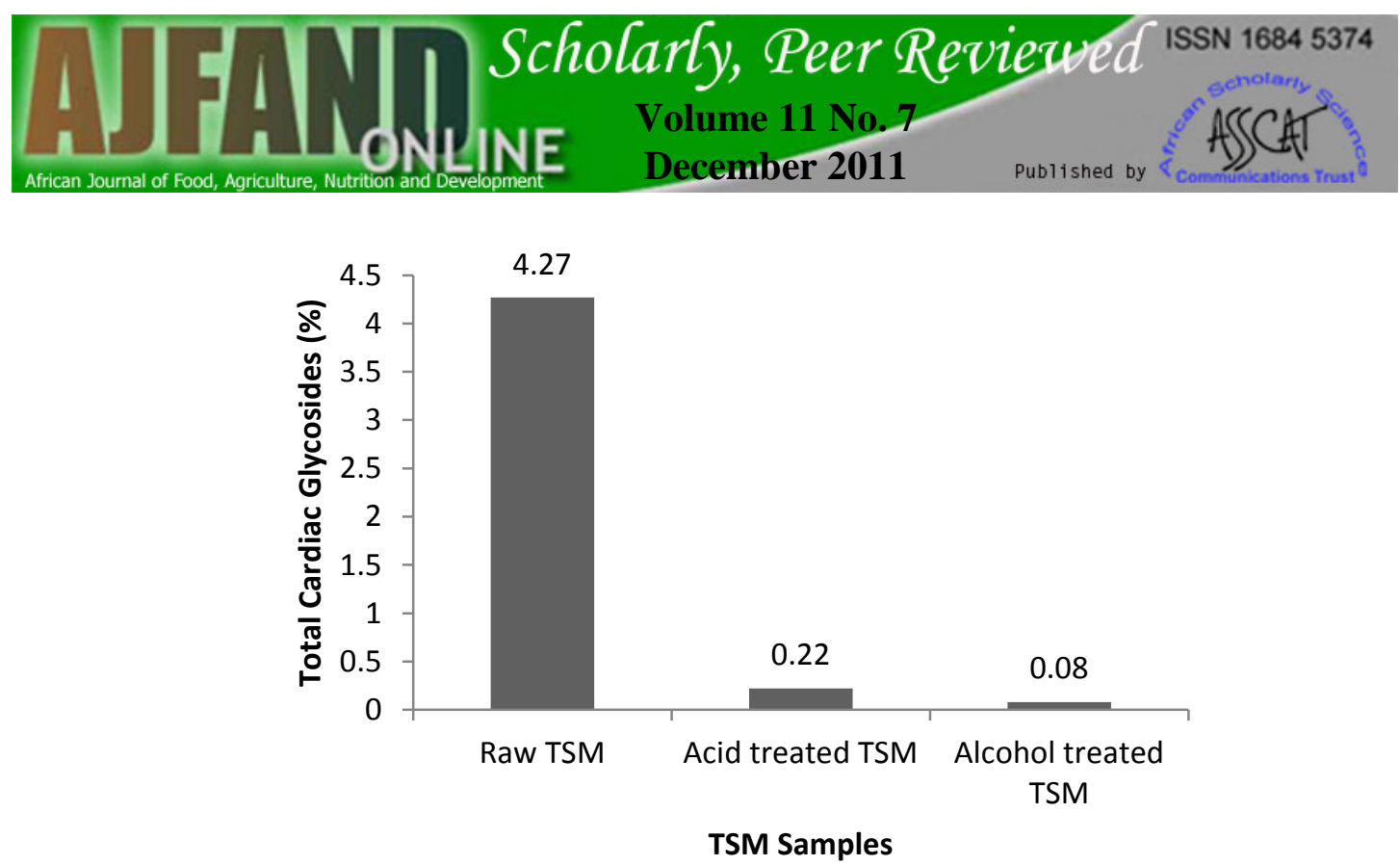

Figure 1: Cardiac glycoside contents of detoxified TSM

\section{Amino acid analysis}

The results of the amino acid analysis are presented in Table 2. All TSM samples (raw and detoxified) contained all the amino acids that were evaluated. The acid amino acids (aspartic and glutamic acid) were the major amino acids (ranging between 14.21 and $21.86 \%$ ) while methionine was the limiting amino acid in all cases (ranging from 0.64 to $0.90 \%$ of the dry matter). The percentage total essential amino acids in all samples ranged from 28.62 to 33.24\%), acid amino acids ranged from 40.34 to $50.04 \%$, basic amino acids from 16.05 to $19.02 \%$ and sulphur amino acids from 2.73 to $3.04 \%$.

\section{Biological evaluation of acid- and alcohol-detoxified TSM}

\section{Trial 1 - Evaluation of acid - detoxified TSM}

The cockerels fed the control diet showed no negative clinical signs and recorded no mortality throughout the duration of the experiment while those on acid-detoxified diets showed variable clinical signs, which increased with time until death, as the level of fed Thevetia seed meal and duration of experiment increased. Some of the signs observed, especially with the high inclusion levels (10 and 15\%) included depressed feed intake and reduced activity. Birds were uncoordinated, staggered about and often walked with a limpy gait. There was also observed a reduction in the weight gain and an increase in the mortality as the inclusion level of acid-treated TSM increased (Table 3). The feed intake ranged from $118 \mathrm{~g} / \mathrm{bird} /$ week in birds on control diet to $68 \mathrm{~g} / \mathrm{bird} /$ week in birds fed diets with the highest inclusion of acid-detoxified meal. The mortality ranged from $0 \%$ in the control birds to $33 \%$ in birds with the highest inclusion of Thevetia. Table 4 shows the results of the nutrient retention for the birds on the acid-detoxified diet. 


\section{Trial 2 - Evaluation of alcohol-detoxified TSM}

Table 5 shows that there was no mortality recorded among the cockerels fed the alcohol-detoxified TSM for the duration of the experiment. The feed intake ranged from $147 \mathrm{~g} / \mathrm{bird} /$ week for control birds to $139 \mathrm{~g} / \mathrm{bird} /$ week for birds on the diet with the highest inclusion of experimental diet. Table 6 shows the results of the nutrient retention of birds on alcohol-detoxified diets. There was little significance and sometimes no significant difference in the performance of this detoxified meal compared with the control diet.

\section{DISCUSSION}

Detoxification of peach kernels led to an improved amino acid profile, with the detoxified meal having a higher percentage of essential, aromatic, sulphur and basic amino acids, while the undetoxified meal had a higher proportion of the non-essential and acid amino acids[29]. Similar trend was observed for TSM where detoxification, especially with alcoholic mixture only, led to an increase in the total, essential, basic and aromatic amino acids (Table 2). Treating with acid prior to alcoholic extraction led to an increase in the non-essential amino acids and the acid amino acids. Alcoholdetoxified TSM generally have an amino acid profile that is very similar to that of the undetoxified (raw) TSM.

The reduced feed consumption of the birds on the experimental diets may be as a result of the residual glycosides in the treated meal since the glycosides of Thevetia have been known to impart a bitter taste in the meal. Earlier studies have reported that Thevetia seeds are unpalatable and their chewing caused slight numbing sensation, a feeling of heat in the mouth, tingling of the tongue and dryness of the throat [30, 31]. This consequently resulted in the low feed consumption and the eventual loss of weight in the cockerels fed acid-treated TSM. The growth inhibition observed in this study could be ascribed to the toxic effects of cardiac glycosides and reduced feed intake, which are suggestive of incomplete detoxification. These results suggest that at the $5 \%$ inclusion levels of treated TSM, even though the feed intake was reduced, the small amount consumed was well utilized. It would then appear that there is a threshold level at which the toxic effect of Thevetia becomes pronounced. This is the level at which the feed efficiency is greatly reduced and the mortality greatly increased.

There was a significant $(\mathrm{p}<0.05)$ reduction in the nutrient retention of birds on the acid-detoxified TSM diet as the level of Thevetia meal in the diets increased (Table 4). The reduction in nutrient retention was attributed to the reduced feed intake and increased faecal weight observed with increased Thevetia intake. These are also attributed to the residual glycosides in the detoxified TSM. Toxic cardiac glycosides have been reported to have a direct stimulatory action on the smooth muscles of the intestine and blood vessel walls leading to gastro intestinal tract irritation, hypermotility, diarrhoea, rapid fluid loss and subsequently dehydration [32].

Within each diet (including control), the fat retention was the highest and the crude fibre retention lowest. This trend was observed in all the dietary treatments. These

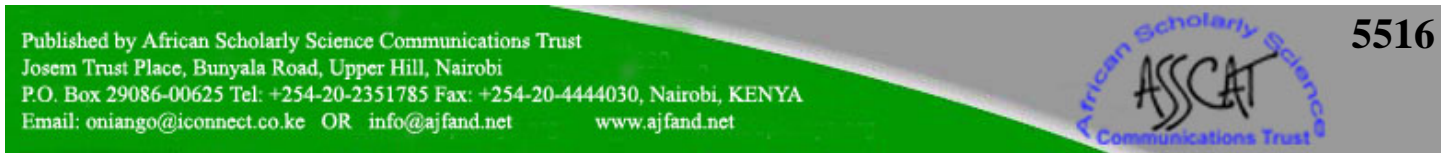


results showed that there has been a great success in the series of attempts to detoxify TSM. No previous detoxification attempts have reported a $0 \%$ mortality or performance pattern that is very similar to that of the control diet. [20, 24, 25]. The results of nutrient retention obtained for birds on the alcohol-detoxified TSM diet (Table 6) further corroborate the better efficiency of alcohol detoxification when compared with acid detoxification. There was a slight reduction in the retention of all nutrients in the 10 and $15 \%$ inclusion levels when compared with the control and $5 \%$ inclusion levels. These decreases were statistically significant, but not enough to cause a significant reduction in the performances of these birds (Table 5).

\section{CONCLUSION}

This study has reported the detoxification of Thevetia seed meal as well as a quantification of the cardiac glycoside content in the treated and untreated samples. The methods reported in this study have been shown to be effective in reducing the glycoside content (toxins) of the seed meal while the residual amounts of glycosides in some of the detoxified samples stand at tolerable levels. The alcohol-detoxified TSM contained a residual amount of glycoside, which did not significantly affect the performance of the birds that were fed with it. All the biological parameters investigated indicated that the performance of the birds on the alcohol-detoxified TSM diets was favourably comparable with that of birds fed on the control diet, thus this detoxification method can be followed up as a potential commercial method for the TSM detoxification. It may be necessary however, to perform the feeding experiment with more birds and over a longer period of time in order to establish the long term effects of utilization of the detoxified seed meal. 


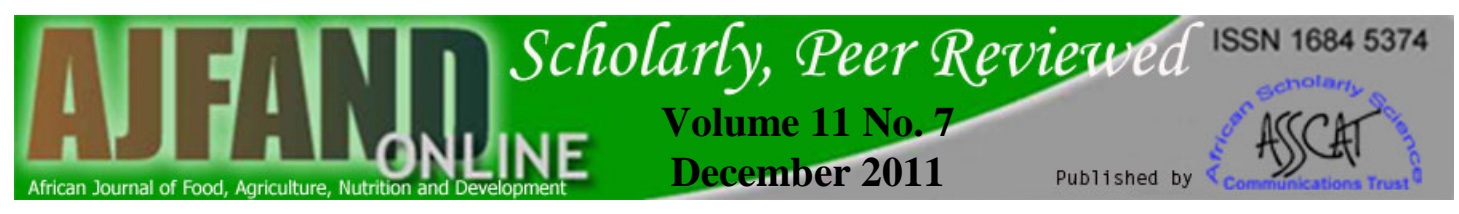

Table 1: Composition of experimental diets (\%).

\begin{tabular}{|c|c|c|c|c|c|c|c|c|}
\hline & Control & T1A & T1B & T1C & Control & T2A & T2B & T2C \\
\hline \multicolumn{9}{|l|}{ Ingredients } \\
\hline Limestone & 2.5 & 2.5 & 2.5 & 2.5 & 2.5 & 2.5 & 2.5 & 2.5 \\
\hline Lysine & 0.1 & 0.1 & 0.1 & 0.1 & 0.1 & 0.1 & 0.1 & 0.1 \\
\hline Methionine & 0.2 & 0.2 & 0.2 & 0.2 & 0.2 & 0.2 & 0.2 & 0.2 \\
\hline Premix & 0.25 & 0.25 & 0.25 & 0.25 & 0.25 & 0.25 & 0.25 & 0.25 \\
\hline Salt & 0.3 & 0.3 & 0.3 & 0.3 & 0.3 & 0.3 & 0.3 & 0.3 \\
\hline Maize & 48.95 & 48.95 & 48.95 & 48.95 & 48.95 & 48.95 & 48.95 & 48.95 \\
\hline Wheat offal & 12.5 & 12.7 & 12.9 & 13.1 & 12.5 & 13.45 & 14.40 & 15.35 \\
\hline Soybean meal & 30.0 & 25.0 & 20.0 & 15.0 & 30.0 & 25.0 & 20.0 & 15.0 \\
\hline Thevetia meal & 0.0 & 5.0 & 10.0 & 15.0 & 0.0 & 5.0 & 10.0 & 15.0 \\
\hline Fish meal & 2.0 & 2.0 & 2.0 & 2.0 & 2.0 & 2.0 & 2.0 & 2.0 \\
\hline Blood meal & 3.2 & 3.0 & 2.8 & 2.6 & 3.2 & 2.25 & 1.3 & 0.35 \\
\hline \multicolumn{9}{|l|}{$\begin{array}{l}\text { Calculated } \\
\text { nutrient } \\
\text { content }\end{array}$} \\
\hline Metabolizable & 2873 & 2866 & 2859 & 2852 & 2873 & 2859 & 2844 & 2830 \\
\hline \multicolumn{9}{|l|}{ Energy (ME) } \\
\hline Crude protein & 23.00 & 23.00 & 23.00 & 23.00 & 23.00 & 23.00 & 23.00 & 23.00 \\
\hline Ether extract & 3.55 & 3.62 & 3.69 & 3.77 & 3.55 & 3.65 & 3.74 & 3.83 \\
\hline Crude fibre & 4.06 & 3.90 & 3.75 & 3.59 & 4.06 & 3.96 & 3.85 & 3.75 \\
\hline
\end{tabular}




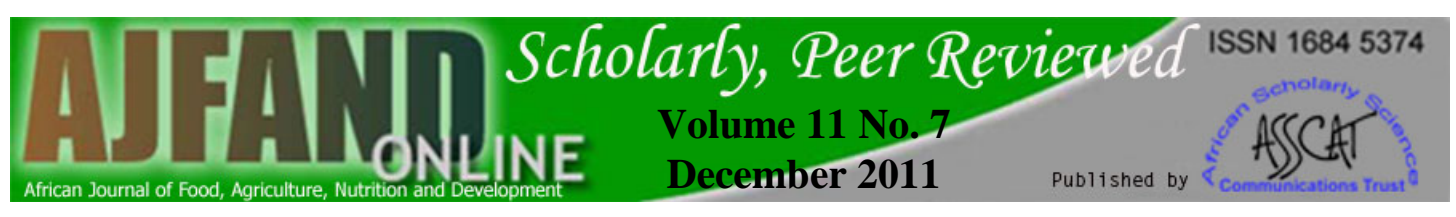

Table 2: Amino acids of TSM (\% dry matter)

\begin{tabular}{|c|c|c|c|}
\hline Amino acid & Undetoxified TSM & $\begin{array}{l}\text { Acid-detoxified } \\
\text { TSM }\end{array}$ & $\begin{array}{l}\text { Alcohol- } \\
\text { detoxified TSM }\end{array}$ \\
\hline Lysine (Lys) $^{\mathrm{a}}$ & 4.47 & 3.97 & 5.65 \\
\hline Histidine (His) ${ }^{b}$ & 1.62 & 1.39 & 1.65 \\
\hline Arginine (Arg) & 4.48 & 4.25 & 5.19 \\
\hline Aspartic acid (Asp) & 19.85 & 21.86 & 20.34 \\
\hline Threonine (Thr) ${ }^{\mathrm{a}}$ & 2.61 & 2.04 & 2.67 \\
\hline Serine (Ser) & 3.93 & 3.12 & 4.00 \\
\hline Glutamic acid (Glu) & 14.21 & 20.10 & 15.67 \\
\hline Proline (Pro) & 4.24 & 3.85 & 4.49 \\
\hline Glycine (Gly) & 3.63 & 2.24 & 3.70 \\
\hline Alanine (Ala) & 4.49 & 3.04 & 4.56 \\
\hline Cysteine (Cys) ${ }^{\mathrm{a}}$ & 1.69 & 1.65 & 1.69 \\
\hline Valine $(\mathrm{Val})^{\mathrm{a}}$ & 4.01 & 3.57 & 4.01 \\
\hline Methionine (Met) ${ }^{\mathrm{a}}$ & 0.88 & 0.64 & 0.90 \\
\hline Isoleucine (Ile) ${ }^{\mathrm{a}}$ & 2.94 & 2.09 & 2.97 \\
\hline Leucine (Leu) ${ }^{\mathrm{a}}$ & 5.49 & 4.88 & 5.59 \\
\hline 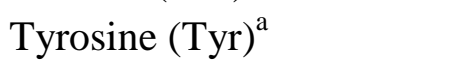 & 2.49 & 1.94 & 2.49 \\
\hline Phenylalanine (Phe) ${ }^{\mathrm{a}}$ & 3.38 & 3.22 & 3.70 \\
\hline Trytophan (Try) $^{\mathrm{a}}$ & ND & ND & ND \\
\hline Total Amino acids & 84.41 & 83.85 & 89.27 \\
\hline \% Difference & & $-0.66 \%$ & $5.76 \%$ \\
\hline $\begin{array}{c}\text { Total Essential Amino } \\
\text { Acids (TEAA) }\end{array}$ & 27.96 & 24.00 & 29.67 \\
\hline \% TEAA & $33.12 \%$ & $28.62 \%$ & $33.24 \%$ \\
\hline $\begin{array}{l}\text { Total Acid Amino Acids } \\
\text { (TAAA) }\end{array}$ & 34.06 (40.35\%) & 41.96 (50.04\%) & 36.01 (40.34\%) \\
\hline $\begin{array}{c}\text { Total Basic Amino Acids } \\
\text { (TBAA) }\end{array}$ & 10.57 (12.52\%) & $9.61(11.46 \%)$ & 12.49 (13.99\%) \\
\hline $\begin{array}{c}\text { Total Sulphur Amino } \\
\text { Acids (TSAA) }\end{array}$ & 2.57 (3.04\%) & $2.29(2.73 \%)$ & $2.59(2.90 \%)$ \\
\hline $\begin{array}{l}\text { Total Aromatic Amino } \\
\text { Acids (TArAA) }\end{array}$ & 7.49 (8.87\%) & $6.55(7.81 \%)$ & 7.84 (8.78\%) \\
\hline
\end{tabular}

${ }^{\mathrm{a}}$ Essential amino acids according to FAO/WHO [33]; ND = Not determined; Values in parentheses are expressed as \% of total amino acids. 


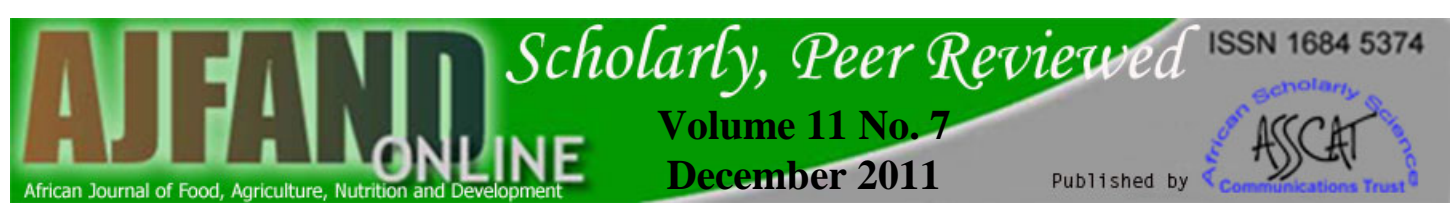

Table 3: Effect of acid-detoxified TSM-based diets on the feed intake, weight gain and gain: feed ratio of birds

\begin{tabular}{ccccc}
\hline Diets & Feed intake & Weight gain & Gain: feed ratio & Mortality \\
& /bird/week (g) & /bird/week (g) & & $\mathbf{( \% )}$ \\
\hline Control & $117.93 \pm 5.49^{\mathrm{a}}$ & $33.40 \pm 4.16^{\mathrm{a}}$ & 0.283 & 0.00 \\
$\mathbf{T 1 A}$ & $96.03 \pm 8.64^{\mathrm{b}}$ & $20.48 \pm 5.52^{\mathrm{b}}$ & 0.213 & 8.33 \\
T1B & $72.30 \pm 6.54^{\mathrm{c}}$ & $4.18 \pm 6.46^{\mathrm{c}}$ & 0.058 & 25.00 \\
$\mathbf{T 1 C}$ & $68.33 \pm 4.38^{\mathrm{c}}$ & $0.15 \pm 2.46^{\mathrm{c}}$ & 0.002 & 33.33 \\
\hline
\end{tabular}

a,b,.. Values are means \pm standard deviations of triplicate determinations. Values in the same column sharing the same superscript letters are not significantly different $(\mathrm{p}>0.05)$

Table 4: Nutrient retention (\%) of birds on acid-detoxified TSM

\begin{tabular}{lclll}
\hline \multicolumn{1}{c}{ Diets } & Nitrogen & Fat & Ash & Crude Fibre \\
\hline Control & $78.83 \pm 1.06^{\mathrm{a}}$ & $74.95 \pm 4.25^{\mathrm{a}}$ & $73.84 \pm 1.99^{\mathrm{a}}$ & $61.68 \pm 8.18^{\mathrm{a}}$ \\
T1A & $71.53 \pm 2.17^{\mathrm{b}}$ & $72.69 \pm 2.27^{\mathrm{a}}$ & $70.83 \pm 2.47^{\mathrm{a}}$ & $54.78 \pm 9.74^{\mathrm{a}}$ \\
& $56.34 \pm 6.51^{\mathrm{c}}$ & $67.07 \pm 3.90^{\mathrm{b}}$ & $50.18 \pm 11.95^{\mathrm{b}}$ & $31.13 \pm 7.54^{\mathrm{b}}$ \\
T1B & $47.65 \pm 5.34^{\mathrm{d}}$ & $58.26 \pm 4.01^{\mathrm{b}}$ & $40.92 \pm 8.78^{\mathrm{b}}$ & $17.74 \pm 17.48^{\mathrm{b}}$ \\
& & & \\
T1C & & & \\
\hline $\begin{array}{l}\text { a,b,.. Values are means } \pm \text { standard deviations of quadruplicate determinations. Values in } \\
\text { the same column sharing the same superscript letters are not significantly different } \\
(\mathrm{p}>0.05)\end{array}$
\end{tabular}




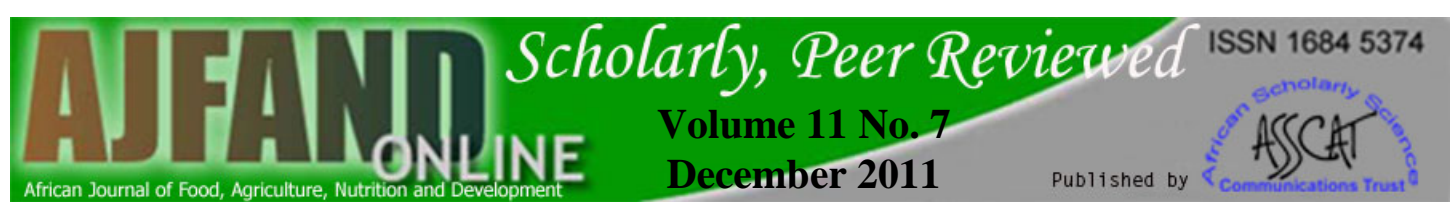

Table 5: Effect of alcohol-detoxified TSM-based diets on the feed intake, weight gain and gain: feed ratio of birds

\begin{tabular}{lrccc}
\hline \multicolumn{1}{c}{ Diets } & Feed intake & Weight gain & Gain: Feed ratio (feed & Mortality \\
& /bird/week & /bird/week & efficiency ratio) & (\%) \\
\hline Control & $147.38 \pm 8.67^{\mathrm{a}}$ & $39.94 \pm 6.11^{\mathrm{a}}$ & $0.27 \pm 0.41^{\mathrm{a}}$ & 0.00 \\
T2A & $150.88 \pm 1.51^{\mathrm{a}}$ & $35.00 \pm 1.94^{\mathrm{a}, \mathrm{b}}$ & $0.23 \pm 0.25^{\mathrm{b}}$ & 0.00 \\
T2B & $144.53 \pm 2.51^{\mathrm{a}, \mathrm{b}}$ & $33.48 \pm 2.62^{\mathrm{b}}$ & $0.23 \pm 0.38^{\mathrm{b}}$ & 0.00 \\
T2C & $138.90 \pm 3.91^{\mathrm{b}}$ & $29.53 \pm 0.90^{\mathrm{b}}$ & $0.21 \pm 0.45^{\mathrm{b}}$ & 0.00 \\
\hline
\end{tabular}

a,b,.. Values are means \pm standard deviations of triplicate determinations. Values in the same column sharing the same superscript letters are not significantly different $(\mathrm{p}>0.05)$

Table 6: Nutrient retention (\%) of birds on alcohol detoxified Thevetia seed meal

\begin{tabular}{|c|c|c|c|c|}
\hline Diets & Nitrogen & Fat & Ash & Crude fibre \\
\hline Control & $79.04 \pm 2.37^{\mathrm{a}}$ & $74.95 \pm 4.25^{\mathrm{a}}$ & $74.51 \pm 0.66^{\mathrm{a}}$ & $62.34 \pm 7.11^{\mathrm{a}}$ \\
\hline T2A & $78.55 \pm 1.68^{\mathrm{a}}$ & $72.02 \pm 0.60^{\mathrm{a}}$ & $76.35 \pm 3.74^{\mathrm{a}}$ & $64.51 \pm 5.81^{\mathrm{a}}$ \\
\hline T2B & $74.78 \pm 2.83^{b}$ & $68.79 \pm 0.67^{b}$ & $71.04 \pm 6.24^{\mathrm{a}, \mathrm{b}}$ & $56.89 \pm 3.79^{\mathrm{a}, \mathrm{b}}$ \\
\hline T2C & $73.61 \pm 0.74^{\mathrm{b}}$ & $67.37 \pm 0.62^{b}$ & $65.53 \pm 3.22^{b}$ & $53.12 \pm 4.50^{\mathrm{b}}$ \\
\hline
\end{tabular}




\section{REFERENCES}

1. McGuigan SM and WL Nieuwoudt Projecting international demand for and supply for protein feed. Agrekon: Agricultural Economics Research Policy and Practice in South Africa. 2001; 40(3): 361 - 392.

2. Speedy AW Overview of world feed protein needs and supply. In Proceedings on Protein Sources for the Animal Feed Industry Expert Consultation and Workshop. Bangkok, 29 April - 3 May 2002: Food and Agriculture Organization of the United Nations, Rome.

3. Corbett RR Peas as a protein and energy source for ruminants. Advances in Dairy Technology 1997; 9: 213 - 247.

4. Bajjalieh N Proteins from Oilseeds. In Proceedings on Protein sources for the animal feed industry. Expert Consultation and Workshop. Bangkok, 29 April 3 May 2002: Food and Agriculture Organization of the United Nations, Rome.

5. Rivas R, Deuch JE and JC Caygill Nitrogen extractability of Sesame Seed (Sesamum indicum L.) and the preparation of two Protein Isolates. J. Sci. Food. Agric. 1981; 32: 565 - 573.

6. Hanafy MM, Seddik $\mathbf{Y}$ and MK Aref Formulation of a protein rich vegetable mixture for prevention of protein calorie malnutrition. J. Sci. Food Agric. 1970; 21: 9 - 18.

7. Ekpenyong TE, Fetuga BL and VA Oyenuga Fortification of maize flour based diets with blends of cashewnut meal, African locust bean meal and sesame oil meal. J. Sci. Food Agric. 1977; 28: 710 - 716.

8. Adegbola AA Indigenising the Poultry Industry in Africa. In Rural Poultry in Africa. Proceedings of an International Workshop on Rural Poultry Development in Africa. (Sonaiya, E.B. Ed.) Ile-Ife, Nigeria: African network on Rural Poultry Development. 1990: 19 - 23.

9. Rahma EH, El-Adawy TA, Laszitity R, Gomaa MA, El-Badawey AA and J Gaugecz Biochemical Studies of some non-conventional sources of proteins. Part 7. Effect of detoxification treatments on the nutritional quality of apricot kernels. Chem. Abst. 1994; 121: 7668z.

10. Steyn DG The Toxicology of Plants in South Africa. IDC, Johannesburg 1934.

11. Nair AGR, Gunasegaran R and BS Joshi Chemical investigation of certain South Indian plants. Indian Journal of Chemistry, 1982; 21b: 979-980. 
12. Ibiyemi SA, Fadipe VO, Akinremi OO and SS Bako Variation in Oil Composition of Thevetia peruviana juss (Yellow Oleander) Fruits Seeds. $J$. Appl. Sci. Environ. Mgt. 2002; 6 (2): 61-65.

13. Atteh JO, Ibiyemi SA and AO Ojo Response of Broilers to Dietary Levels of Thevetia Cake. J. Agr. Sci. Cambridge. 1995; 125: 307 - 310.

14. Aleshkina YA and VV Berezhinskaya Pharmacology of the glycosides of Thevetia neriifolia. Farmakol. i Toksikol 1962; 25: 720-725.

15. Bisset NG Cardiac glycosides IV. Apocynaceae: A preliminary paper chromatographic studies of the glycosides from T. peruviana. Ann. Bogor 1963; 4(2): 145-152.

16. Chen KK and FG Handerson Cardiac activity of apocynaceous glycosides and aglycons. Arch. Intern. Pharmacodyn. 1962; 140: 8-19.

17. Ching-Chang $\mathbf{H}$, Keng-Hsing $\mathbf{H}$ and $\mathbf{L}$ Shao-Hsien Pharmacology of the glycosides of T. peruviana. Chem. Abstract 1966; 64: 18275d.

18. Sticher $\mathbf{O}$ Theveside, a new iridoid glycoside from Thevetia peruviana. Tetrahedron Lett. 1970; 36: 3195-3196.

19. Eddleston $\mathbf{M}$ and DA Warrell Management of acute yellow oleander poisoning. QJ Med 1999; 92: 483-485.

20. Orji $\mathbf{O}$ and QE Okafor Toxicological studies on the stem bark, leaf and seed kernel of yellow oleander (Thevetia peruviana). Phytother Res. 2000; 14(2): $133-135$.

21. Eddleston M, Ariaratnam CA, Sjostrom L, Jayalath S, Rajakanthan K, Rajapakse S, Colbert D, Meyer WP, Perera G, Attapattu S, Kularatne SAM, Sheriff MR and DA Warell Acute yellow oleander poisoning: cardiac arrhythmias, electrolyte disturbances, and serum cardiac glycoside concentrations on presentation to hospital. Heart 2000; 83: $301-306$.

22. Perez-Amador M, Bratoeff EA and SB Hernandez Thevetoxide and Digitoxigenin, cardenolides from two species of Thevetia (Apocynaceae). Phyton (Buenos Aires) 1993; 54(2): 99-102.

23. Huang CC, Hung KH and SH Lo Pharmacology of the glycosides of Thevetia peruviana I. Thevetin. Yao Hsueh Hsueh Pao 1965; 12(2): 824-826 (Ch.)

24. Odetokun SM, Akindumila F and EO Ibukun Assessment of protein cake of bush milk flower (Thevetia peruviana) in poultry feed. La Rivista Italiana Delle Sostanze Grasse. 1999; LXXVI: 233 - 235. 
25. Taiwo VO, Afolabi OO and OA Adegbuyi Effect of Thevetia peruviana seed cake - based meal on the growth, haematology and tissues of rabbits. Tropical and Subtropical Agroecosystems 2004; 4: 7 - 14.

26. Oluwaniyi OO, Ibiyemi SA and LA Usman Effect of detoxification on the nutrient content of Thevetia peruviana seed cake. Research Journal of Applied Science 2007; 2(2): 188 - 191.

27. El-Olemy MM, Al-Muhtadi FJ and A-FA Afifi Experimental Phytochemistry: A Laboratory Manual. King Saud University Press. Saudi Arabia, 1994: 21 - 27.

28. AOAC. International Official methods of analysis, Association of Official Analytical Chemists, Maryland 2005.

29. El-Adawy TA and SA El-Kadousy Changes in chemical composition, nutritional quality, physico-chemical and functional properties of peach kernel meal during detoxification. Food Chemistry 1995; 52: 143 - 148.

30. Begum S, Abii O, Siddiqui BS and S Siddiqui Constituents of the leaves of Thevetia neriifolia. Journal of Natural Products, 1993; 56: 613-617.

31. Space JC, Waterhouse BM, Miles JE, Tiobech $\mathbf{J}$ and $\mathbf{K}$ Rengulbai Report to the Republic of Palau on invasive plant species of environmental concern. USDA Forest Service, Honolulu, 2003; 179pp.

32. Watt JM and MG Breyer - Brandwijk (Ed.) The Medicinal \& Poisonous plants of Southern and Eastern Africa. E \& S Livingstone Ltd, Edinburgh \& London. 1962: 107 - 109.

33. FAO/WHO/UNU. Energy and protein requirement, WHO Technical Report Series 1985; No. 724, Geneva, Switzerland. 